\title{
FUERO MILITAR: SUS ALCANCES Y LIMITACIONES
}

\author{
José Ramón Cossío DíAZ ${ }^{1}$
}

En sesión del 10 de agosto de 2009, el Pleno de esta Suprema Corte de Justicia de la Nación resolvió por mayoría de seis votos sobreseer el juicio del amparo en revisión 989/2008. Ello, al considerar que la quejosa en el amparo - por tener la calidad de ofendida en el delito de homicidio cometido en agravio de su esposo, presuntamente por miembros del Ejército Mexicanono tiene la legitimación activa para acudir al juicio a reclamar la inconstitucionalidad del artículo 57, fracción II, inciso a) del Código de Justicia Militar. Disposición que faculta a los tribunales militares para conocer de aquellos delitos del orden común o federal que son cometidos por militares en los momentos de estar en servicio o con motivo de actos del mismo.

\section{ANTECEDENTES DEL ASUNTO}

Como antecedentes del asunto debe destacarse:

$\mathrm{El}$ asunto que se somete a consideración tiene origen en los siguientes hechos: el 26 de marzo de 2008, en las inmediaciones de la comunidad de Santiago los Caballeros, municipio de Badiraguato, Sinaloa, un grupo de civiles que viajaba en un vehículo particular por la carretera a Navolato, km. 9.5, recibió impactos de bala desde otro vehículo tripulado por personal del Ejército mexicano. Con motivo de ello, cuatro civiles perdieron la vida.

1 Voto particular que formula el Ministro José Ramón Cossío Díaz en el amparo en revisión 989/2008, fallado por la Tribunal Pleno de la Suprema Corte de Justicia de la Nación en sesión de 10 de agosto de 2009. El autor agradece la colaboración de Miguel Enrique Sánchez Frías, Patricia del Arenal Urueta, Alberto Cepeda Orvañanos y Karlos A. Castilla Juárez, en la elaboración de este documento. 
A consecuencia de los hechos, el Ministerio Público de la Federación inició una averiguación previa; sin embargo, posteriormente declinó competencia en favor del fuero militar. Así, la Procuraduría General de Justicia Militar consignó ante un juez militar la averiguación previa en la que cinco militares fueron señalados como probables responsables.

La esposa de uno de los civiles fallecidos acudió al amparo - en su calidad de ofendida por el delito de homicidio-, impugnando la constitucionalidad del artículo 57, fracción II, inciso a, del Código de Justicia Militar que permitió que un juez militar se declarara competente para conocer de la causa penal antes referida.

La quejosa argumentó que la norma impugnada resulta contraria a los límites establecidos en el artículo 13 constitucional para la actualización de la competencia del fuero militar. Ello, al otorgar competencia a los tribunales militares para conocer de delitos no estrictamente relacionados con la disciplina militar y/o en los que la víctima (o el ofendido) tiene la calidad de civil.

El juez de distrito respectivo admitió la demanda de amparo, solicitó los informes justificados a las autoridades responsables y al dictar sentencia determinó sobreseer en el juicio alegando que la quejosa carecía de interés jurídico, en términos de lo dispuesto en el numeral 74, fracción III, de la Ley de Amparo, al haberse actualizado la causal de improcedencia prevista en la fracción V del artículo 73 de la Ley de Amparo.

Con motivo de esta resolución, la ofendida del delito interpuso recurso de revisión, mismo que fue atraído por la Primera Sala de la Suprema Corte de Justicia de la Nación, en atención al interés y trascendencia del tema planteado; a saber: determinar si el ofendido tiene interés jurídico para acudir al juicio de garantías e impugnar tanto las normas como los actos de un proceso penal seguido ante autoridad castrense. La Sala consideró desde entonces que para dar una respuesta al tema planteado resultaba necesario, al menos, interpretar los artículos 13, 17 y 20, apartado $\mathrm{B}$, constitucionales, en relación a los numerales 10 y 73, fracción $\mathrm{V}$, de la Ley de Amparo.

\section{RESOlUCiÓN DEL TRIBUNAL PlenO}

La mayoría que integra el Pleno consideró que el sobreseimiento decretado por el juez de distrito debía confirmarse. Ello — se consideró- 
porque la víctima o el ofendido no gozan de legitimación activa para acudir al amparo a solicitar la inconstitucionalidad del artículo 57, fracción II, inciso a) del Código de Justicia Militar en virtud de que la norma no afecta su interés jurídico. Por tanto, la mayoría de los ministros consideró que resultaba aplicable la causal de improcedencia prevista en la fracción V del artículo 73 de la Ley de Amparo. ${ }^{2}$

Tal consideración no se comparte. Las razones por las que se considera que la ofendida sí cuenta con interés jurídico para acudir al amparo a reclamar la inconstitucionalidad de la norma citada, están ya expuestas en el voto de minoría que se formuló con el propósito del sobreseimiento decretado por el Pleno.

Ahora bien, el presente voto particular se formula con el fin de presentar la interpretación del artículo 13 constitucional que fue puesta a consideración del Pleno y cuyo análisis simplemente no abordó. Es decir, el fin es presentar la contestación que — se considera- el Pleno debió dar a los planteamientos de la quejosa.

\section{CONSIDERACIONES DEL PRESENTE VOTO}

Las consideraciones que motivan el presente voto únicamente versan sobre la inconstitucionalidad del artículo 57, fracción II, inciso a) del Código de Justicia Militar, que fue planteada por la quejosa.

En su segundo concepto de violación, la quejosa señala que el artículo 57, fracción II, inciso a), del Código de Justicia Militar viola lo previsto en el artículo 13 constitucional, toda vez que faculta a los Tribunales Militares para que extiendan su jurisdicción sobre las personas que no pertenecen a las fuerzas armadas.

La quejosa argumenta que el Constituyente estableció límites precisos a la jurisdicción castrense, ordenando que ésta se acotara a los delitos y a las faltas contra la disciplina militar; por ello, si la ley secundaria - Código de Justicia Militar - amplía dicha competencia, entonces resulta inconstitucional. Añade que mientras la Constitución limita el fuero de guerra a aquellos delitos y faltas que atenten contra la disciplina militar,

2 Artículo 73. El juicio de amparo es improcedente: V. Contra actos que no afecten los intereses jurídicos del quejoso. 
el Código de Justicia Militar introduce diversos supuestos no relacionados con lo normado por la Constitución.

Pues bien, del análisis de los argumentos expuestos por la quejosa en tal concepto de violación, se arriba al convencimiento de que el mismo resultaba fundado.

Para justificar lo anterior es indispensable hacer una referencia a los antecedentes constitucionales e históricos del artículo 13 constitucional, ello para estar en aptitud de realizar la interpretación que -se considera- debe regir, misma que debe confrontarse con precepto impugnado a efecto de analizar su inconstitucionalidad.

\section{Antecedentes constitucionales e históricos}

Al hacer un análisis de los antecedentes constitucionales e históricos del artículo 13 constitucional, se advierte que la jurisdicción del fuero militar o de guerra, hasta antes de la promulgación de la Ley sobre Administración de Justicia y Orgánica de los Tribunales de la Nación, del Distrito y Territorios (Ley Juárez) —el 22 de noviembre de 1855- no se limitaba a la concedida a tribunales especiales para juzgar a miembros del ejército, sino que comprendía un conjunto de preceptos que establecían privilegios y exenciones en favor de los militares, tanto en negocios del orden civil, como en el caso de causas criminales sobre delitos del orden común y en los comprendidos en la ordenanza militar.

Tal fue la tendencia desde el contenido de la Constitución de Cádiz (1812), ${ }^{3}$ pasando por el Reglamento Provisional Político del Imperio Mexicano ${ }^{4}$ e in-

3 El artículo 250 de la Constitución Política de la Monarquía Española, promulgada en Cádiz el 19 de marzo de 1812, establecía lo siguiente: “Artículo 250. Los militares gozarán también de fuero particular, en los términos que previene la ordenanza o en adelante previniere".

4 El artículo 57 del Reglamento Provisional Político del Imperio Mexicano, suscrito en la ciudad de México el 18 de diciembre de 1822, establecía lo siguiente: "Artículo 57. Subsisten los juzgados y fueros militares y eclesiásticos, para los objetos de su atribución; como los peculiares de minería y de Hacienda Pública, que procederán como hasta aquí, según la ordenanza y leyes respectivas." 
cluso la Constitución Federal de $1824^{5}$ y otras disposiciones de la época. ${ }^{6}$

Así, la llamada Ley Juárez, en sus artículos 42 y 4o. transitorio, suprimía a los tribunales especiales, con excepción de los eclesiásticos y militares, estableciendo que estos últimos debían cesar de conocer de los negocios civiles, debiendo tan sólo conocer de los delitos puramente militares o mixtos de los individuos sujetos al fuero de guerra. Así, tal Ley obligaba a los tribunales militares a pasar a los jueces ordinarios los negocios civiles y las causas criminales sobre delitos comunes. ${ }^{7}$

De lo anterior también se observa que hasta antes de la promulgación de la citada Ley, la aplicación del fuero de guerra obedecía a un criterio personal. Al igual que el fuero eclesiástico, el de guerra era aplicado en favor de todos los individuos pertenecientes a la institución castrense por ese solo motivo.

Sin embargo, a partir de la promulgación de la Ley sobre Administración de Justicia y Orgánica de los Tribunales de la Nación, del Distrito y Territorios (Ley Juárez), se originó un cambio en el criterio que determina la competencia del fuero de guerra, limitándolo a la jurisdicción concedida a tribunales especiales para juzgar a miembros del ejército. Dicho cambio extrajo de la esfera de competencias de los tribunales militares, los negocios del orden común, así como las causas criminales sobre delitos del orden común.

5 El artículo 154 de la Constitución Federal de los Estados Unidos Mexicanos, sancionada por el Congreso General Constituyente el 4 de octubre de 1824, establecía lo siguiente: "Artículo 154. Los militares y eclesiásticos continuarán sujetos a las autoridades a que lo están en la actualidad según las leyes vigentes".

6 Finalmente, el artículo 30 de la quinta, de las Leyes Constitucionales de la República Mexicana, suscritas en la ciudad de México el 29 de diciembre de 1836, establecía lo siguiente: "Artículo 30. No habrá más fueros personales que el eclesiástico y militar".

7 Artículo 42. Se suprimen los tribunales especiales, con excepción de los eclesiásticos y militares. Los tribunales eclesiásticos cesarán de conocer en los negocios civiles, y continuarán conociendo de los delitos comunes de los individuos de su fuero, mientras se expide una ley que arregle ese punto. Los tribunales militares cesarán también de conocer de los negocios civiles, y conocerán tan sólo de los delitos puramente militares o mixtos de los individuos sujetos al fuero de guerra. Las disposiciones que comprende ese artículo, son generales para toda la República, y los Estados no podrán variarlas o modificarlas. Artículo 4o transitorio. Los tribunales militares pasarán igualmente a los jueces ordinarios respectivos, los negocios civiles y causas criminales sobre delitos comunes: lo mismo harán los tribunales eclesiásticos con los negocios civiles en que cesa su jurisdicción. 
De esta manera, el artículo 42 de la llamada Ley Juárez limitaba la competencia de los tribunales militares al conocimiento de las causas criminales sobre delitos puramente militares o mixtos cometidos por los miembros del ejército. Es decir, sobreviene un cambio de criterio en la aplicación del fuero de guerra, de un criterio estrictamente personal a un criterio material: la comisión de un delito militar.

Este mismo criterio es retomado en el Estatuto Orgánico Provisional de la República Mexicana, decretado por el Supremo Gobierno el 15 de mayo de 1956, el cual limitaba la competencia de los tribunales militares al conocimiento de los delitos cometidos por miembros del ejército en el servicio militar. ${ }^{8}$

Posteriormente, los miembros del Congreso General Constituyente de 1857 acotaron aún más la competencia de los tribunales militares, estableciendo en el artículo 13 de la Constitución Política de la República Mexicana que el fuero de guerra subsistía solamente para los delitos y faltas que tuvieren exacta conexión con la disciplina militar, reservando a la ley secundaria la facultad de fijar dichos casos de excepción. ${ }^{9}$

Así, bajo la vigencia de la Ley sobre Administración de Justicia y Orgánica de los Tribunales de la Nación, del Distrito y Territorios (Ley Juárez), y particularmente de la Constitución Política de la República Mexicana de 1857, el fuero de guerra dejó de constituir un régimen diferenciado de privilegios y de exenciones en favor de los militares, para convertirse el criterio que limitaría la competencia de los tribunales militares para conocer de los delitos y faltas con exacta conexión con la disciplina militar.

Ahora bien, del análisis del Diario de los Debates del Congreso Constituyente de 1916-1917, se advierte que las discusiones entre sus inte-

8 El artículo 77 de esta Ley disponía: "Estas garantías son generales, comprenden a todos los habitantes de la República y obligan a todas las autoridades que existen en ella. Únicamente queda sometido a lo que dispongan las leyes comunes generales: I. El modo de proceder contra los militares en los delitos cometidos en el servicio militar".

9 El artículo 13 de la Constitución Política de la República Mexicana, sancionado por Congreso General Constituyente, establecía: “Artículo 13. En la República mexicana nadie puede ser juzgado por leyes privativas, ni por tribunales especiales. Ninguna persona o corporación puede tener fueros, ni gozar de emolumentos que no sean compensación de un servicio público y estén fijados por la ley. Subsiste el fuero de guerra solamente para los delitos y faltas que tengan exacta conexión con la disciplina militar. La ley fijará con toda claridad los casos de esta excepción." 
grantes tuvieron como principal objeto, determinar si debía subsistir o no el fuero militar o de guerra.

El dictamen presentado por la Comisión de Constitución del Congreso Constituyente de 1916-1917 proponía conservar el fuero de guerra, considerándolo necesario para mantener la disciplina en el ejército, opinión que no era unánime. Sin embargo, también se argumentó de manera clara que con el proyecto se buscaba circunscribir aún más la jurisdicción de los tribunales militares, retirándoles aquélla de modo absoluto respecto de los civiles implicados en delitos del orden militar. Literalmente se expresó: "el fuero militar responde exactamente a la necesidad social que hace forzosa su subsistencia; viene a constituir una garantía para la misma sociedad, en lugar de un privilegio otorgado a la clase militar, como fue en otro tiempo". ${ }^{10}$

Por su parte, el general Francisco J. Múgica formuló un voto particular en el que criticó la subsistencia del fuero de guerra y señaló la conveniencia de abolirlo, para que en su lugar los tribunales ordinarios conocieran de los delitos contra la disciplina militar. ${ }^{11}$

Esteban B. Calderón propuso que se independizara la justicia militar del Poder Ejecutivo y se le ubicara dentro del Poder Judicial de la Federación. ${ }^{12}$ Asimismo, Hilario Medina cuestionó el militarismo, afirmando que uno de los fines de la Revolución mexicana había sido acabar con el militarismo y que, aun cuando el Congreso aprobase el artículo propuesto por la Comisión consignando el fuero, quedaría como un legado para las futuras generaciones la abolición definitiva del fuero de guerra. ${ }^{13}$ Finalmente, el artículo 13 fue aprobado por 122 votos contra 61, con la redacción actual. ${ }^{14}$

10 Marván Laborde, Ignacio, Nueva Edición del Diario de Debates del Congreso Constituyente de 1916-1917, Tomo I, Suprema Corte de Justicia de la Nación, México, 2005 , p. 646.

11 Ibidem, pp. 647-650.

12 Ibidem, pp. 661-664.

13 Ibidem, pp. 667-672.

14 Artículo 13. Nadie puede ser juzgado por leyes privativas ni por tribunales especiales. Ninguna persona o corporación puede tener fuero, ni gozar más emolumentos que los que sean compensación de servicios públicos y estén fijados por la ley. Subsiste el fuero de guerra para los delitos y faltas contra la disciplina militar; pero los tribunales militares en ningún caso y por ningún motivo podrán extender su jurisdicción sobre personas que 
En el ámbito jurisdiccional, los antecedentes históricos también nos brindan importantes elementos, ya que entre los años de 1919 y 1933, esta Suprema Corte de Justicia de la Nación sostuvo en diversas tesis aisladas, una interpretación del artículo 13 constitucional conforme con la intención del Congreso Constituyente de 1916-1917. Es decir, desarrolló y mantuvo un criterio estrictamente material — delitos y faltas contra la disciplina militar - para otorgar competencia a los tribunales militares y, de conformidad con lo dispuesto en la última parte del artículo 13 constitucional, estableció de manera clara que debía otorgarse competencia a los jueces civiles en los casos en que concurrieran militares y paisanos o civiles. ${ }^{15}$

no pertenezcan al Ejército. Cuando en un delito o falta del orden militar estuviese complicado un paisano, conocerá del caso la autoridad civil que corresponda.

15 Los siguientes criterios fueron resultado de dicha interpretación:

FUERO DE GUERRA. No puede extenderse a conocer de delitos que, aunque cometidos por militares, y relacionados con el servicio del Ejército, no son contra la disciplina militar (tesis aislada, Quinta Época, Pleno, Semanario Judicial de la Federación, t. V, p. 900).

Delitos Del Fuero DE GUERRA. No basta que un delito sea cometido por un militar, para que caiga bajo la jurisdicción de los tribunales del fuero de guerra, sino que es preciso que se llenen los requisitos prevenidos por el artículo 13 constitucional (tesis aislada, Quinta Época, Pleno, Semanario Judicial de la Federación, t. VI, p. 853).

DELITOS DEL FUERO DE GUERRA. El fuero de guerra subsiste solamente para los delitos y faltas contra la disciplina militar, cometidos por militares, de suerte que no basta que un delito haya sido cometido por un individuo perteneciente al Ejército, porque si no afecta sfunciones militares, o contra el deber o decoro militar, o en contra de la seguridad o existencia del Ejército, no puede caer bajo la competencia de los tribunales del fuero de guerra (tesis aislada, Quinta Época, Pleno, Semanario Judicial de la Federación, t. VII, p. 1140).

Delitos Del Fuero DE GUERRA. Para que se consideren tales, se necesita que sean cometidos por un militar y que, como consecuencia de ellos, se ocasionen tumultos o desórdenes en la tropa, o interrupciones o perjuicios en el servicio militar (tesis aislada, Quinta Época, Pleno, Semanario Judicial de la Federación, t. X, p. 788).

FUERO DE GUERRA. Si los delitos que cometan los militares, no afectan a la disciplina militar, no son de la competencia del fuero de guerra (Semanario Judicial de la Federación, tesis aislada, Quinta Época, Pleno, t. XII, p. 70).

ARTíCULO 13 CONSTITUCIONAL. El espíritu de esta disposición, en cuanto previene que cuando en un delito o falta del orden militar, estuviese complicado un paisano, conocerá del caso la autoridad civil que corresponda, es que un mismo tribunal resuelva sobre la responsabilidad de los paisanos y de los militares, a fin de que no se divida la continencia de la causa; por lo que, aun cuando en el curso de la averiguación no se formulen 
Sin embargo, a partir de 1933, mismo en que es expedido el Código de Justicia Militar, ${ }^{16}$ esta Suprema Corte de Justicia de la Nación adoptó una interpretación que buscaba compaginar lo dispuesto por el artículo 13 constitucional con lo establecido en el artículo 57 del Código de Justicia Militar, ${ }^{17}$ pretendiendo ajustar y hacer admisible el contenido de la legis-

conclusiones acusatorias contra los paisanos, debe continuar conociendo del proceso el Juez Civil, hasta fallar para que aquella continencia subsista (Semanario Judicial de la Federación, tesis aislada, Quinta Época, Pleno, t. XII, p. 913).

Fuero DE GUERRA. Para que se surta la competencia de los tribunales del fuero de guerra, es preciso que, como consecuencia del delito cometido por militares, se produzca tumulto o desorden en la tropa, o que el servicio militar resulte perjudicado de cualquiera manera; de suerte es que no basta que el delito se cometa por militares y contra militares para que surta la competencia ya dicha, pues la Ley de Organización y Competencia de los Tribunales Militares, de modo claro especifica cuáles son los delitos que tiene exacta conexión con la disciplina militar, y cuáles están sujetos a la competencia de sus tribunales (Semanario Judicial de la Federación, tesis aislada, Quinta Época, Primera Sala, t. XXV, p. 873).

FUERO DE GUERRA. El artículo 13 constitucional limita la órbita de los tribunales militares, fija su jurisdicción exclusivamente sobre aquellas personas que pertenecen al Ejército, y manda, además, que cuando en los delitos del orden militar aparezca complicado un paisano, conocerá del caso la autoridad civil correspondiente; y dados los términos categóricos de ese precepto, aun suponiendo que se trata de investigar el delito de rebelión militar, en el que se hallen inmiscuidos algunos paisanos, los jefes militares no están capacitados para asumir las funciones que el artículo 21 constitucional concede al Ministerio Público, ni para proceder a la detención de los acusados, si en el lugar en donde residen dichos jefes existen autoridades judiciales comunes y funciona normalmente el Ministerio Público (Semanario Judicial de la Federación, tesis aislada, Quinta Época, Primera Sala, t. XXX, p. 1643)

16 Expedido por el C. Abelardo L. Rodríguez, presidente sustituto constitucional de los Estados Unidos Mexicanos, en uso de la facultad conferida al Ejecutivo Federal por el Congreso de la Unión, según decreto de 28 de diciembre del 1932, publicado el 13 de enero de 1933.

17 Artículo 57. Son delitos contra la disciplina militar:

I. Los especificados en el Libro Segundo de este Código;

II. Los del orden común o federal, cuando en su comisión haya concurrido cualquiera de las circunstancias que en seguida se expresan:

a) que fueren cometidos por militares en los momentos de estar en servicio o con motivo de actos del mismo;

b) que fueren cometidos por militares en un buque de guerra o en edificio o punto militar u ocupado militarmente, siempre que, como consecuencia, se produzca tumulto o desorden en la tropa que se encuentre en el sitio donde el delito se haya cometido o se interrumpa o perjudique el servicio militar; 
lación secundaria con el texto constitucional. Al hacerlo, sin embargo, se omitió analizar si el contenido del artículo 57 del Código de Justicia Militar era compatible con el artículo 13 constitucional.

Dicha interpretación quedó plasmada en las siguientes tesis aisladas:

FUERO DE GUERRA. Para interpretar rectamente el artículo 13 de la Constitución, no basta el sentido gramatical, ni son suficientes tampoco, los elementos que proporcionan las discusiones del Congreso Constituyente, porque uno y otras revelan, solamente, que el debate tuvo por objeto esencial, determinar si subsistía o no, el fuero de guerra, prevaleciendo, al final, la consideración de que era necesario que subsistiera. Para interpretarlo conviene considerar el espíritu de esas discusiones, que tendieron a demostrar la necesidad de restringir el fuero de guerra a sus estrictos límites, y aun a suprimirlo, llegándose, por fin, a la conclusión de que un civil no puede ser juzgado, por ningún motivo en ningún caso, por un tribunal militar; mas como el fuero de guerra es indispensable para la defensa del ejército, se deduce que dicho fuero comprende a todas las personas que pertenezcan a esa institución; el último párrafo del artículo 13, que manda que cuando en un delito o falta del orden militar, estuviese complicado un paisano, conozca del caso la autoridad civil que corresponda, se ha querido entender en el sentido de que dicha autoridad civil habrá de conocer del asunto, en su integridad, esto es, que juzgará a los militares y a los civiles; mas de estimarse tal interpretación, se consentiría en nulificar el fuero de guerra, supuesto que los militares quedarían sustraídos a la jurisdicción de los tribunales de su fuero, con notorio desacato del principio constitucional relativo; cierto es que éste manda que los civiles nunca sean juzgados por los tribunales del fuero de guerra, pero de ahí no es lógico deducir que si un civil está inmiscuido con elementos militares, en la comisión de un delito, los militares deban ser enjuiciados y castigados por los tribunales del orden común. Más conforme con el espíritu de las discusiones que precedieron a la redacción del artículo que se comenta, es que lo

c) que fueren cometidos por militares en territorio declarado en estado de sitio o en lugar sujeto a la ley marcial conforme a las reglas del derecho de la guerra;

d) que fueren cometidos por militares frente a tropa formada o ante la bandera;

e) que el delito fuere cometido por militares en conexión con otro de aquellos a que se refiere la fracción I.

Cuando en los casos de la fracción II, concurran militares y civiles, los primeros serán juzgados por la justicia militar.

Los delitos del orden común que exijan querella, necesaria para su averiguación y castigo, no serán de la competencia de los tribunales militares, sino en los casos previstos en los incisos (c) y (e) de la fracción II. 
dispuesto en favor de los civiles, rija en todo caso para ello, pero que no se vulnere el fuero de guerra, haciéndolo nugatorio. Esta interpretación favorece y concilia las dos tendencias que se observan en el artículo 13 constitucional, o sea, que las personas que pertenezcan al ejército, cuando cometan un delito o falta del orden militar, sean juzgadas conforme al fuero de guerra, y que los civiles, en cualquier caso sean enjuiciados y castigados por los tribunales del orden común; el examen atento del repetido artículo, da mayor fuerza a las anteriores conclusiones; en efecto, la excepción a la regla general, establecida por el tan repetido artículo 13, o sea el fuero de guerra, lo fue por razón de la materia o naturaleza de los delitos y porque así se creyó necesario por exigirlo la disciplina militar; en cambio, la prohibición expresa que el mismo contiene, de que los civiles sean enjuiciados por los tribunales militares, se consigna atendiendo a las personas mismas y no a la materia. No es concebible, por otra parte, que la Constitución se contradiga, estableciendo primero el fuero de guerra y después nulificándolo; el sentido natural y lógico indica que la frase "conocer el caso", no puede ser entendida más que en el sentido de que la autoridad civil conozca del caso imputado a los civiles, pero no del proceso que se instruya contra los militares. Algunas ejecutorias de la Corte sostuvieron la competencia de los tribunales civiles, cuando en un delito militar estaban inmiscuidos militares y paisanos, para no dividir la continencia de la causa, pero a esto debe contestarse que no hay propiamente disposición legal alguna que prohíba que el procedimiento de divida; en este caso, cierto es que siguiendo dicho proceso un solo Juez, se facilita la secuela, pero también lo es que cuando se siguen dos procesos ante tribunales de diversos fueros, no se imposibilita la acción de la justicia, porque dichos tribunales pueden aprovechar los mismos elementos, con la ventaja de que cada uno obrará con mejor conocimiento y mayor experiencia, supuesto que aplicará las leyes de su fuero; $y$, además, la doctrina demuestra que no pueden seguirse procesos de distinto fuero, ante autoridad de diferente jurisdicción, y por medio de un solo procedimiento, doctrina que funda la parte final del artículo 329 del Código Federal de Procedimientos Penales, el que, después de fijar los casos de acumulación de procesos, para que no se divida la continencia de la causa, declara que no procederá esa acumulación, si se trata de diversos fueros. Por todo lo anterior, se concluye: I. el artículo 13 constitucional prohíbe que los civiles sean juzgados por los tribunales militares, en todo caso; II. manda que las personas que pertenezcan al ejército, deben ser enjuiciadas ante los tribunales del fuero de guerra, cuando se trata de delitos del orden militar, y III. que cuando en la comisión de un delito del orden militar concurran militares y 
civiles, la autoridad civil debe conocer del proceso, por lo que toca a los civiles, y los tribunales del fuero de guerra, del que se instruya a los militares. ${ }^{18}$

Sin embargo, esta tesis fue contradicha en un caso posterior, dando lugar a la tesis de rubro y texto siguientes:

FUero De GUERRA. Para interpretar debidamente el artículo 13 de la Constitución General, debe atenderse tanto a su redacción como a sus antecedentes históricos y a las condiciones sociales reinantes cuando dicho precepto se expidió. Atendiendo a los antecedentes históricos, se ve que el fuero militar, hasta antes de la independencia de nuestro país, no se limitaba a la jurisdicción concedida a tribunales especiales para juzgar a miembros del ejército, sino que comprendía un conjunto de preceptos que establecían privilegios y exenciones, tanto en materia criminal como en materia civil, en favor de los militares y aun de los miembros de sus familias. Consumada la independencia, como cada uno de los miembros políticos que le sucedieron y que tendieron a la organización del país, estuvo apoyado por medio de las armas, de ahí se originó el que la situación del ejército continuara siendo preponderante, lo cual tuvo por resultado que la Constitución de 1824 dejara subsistentes los fueros de la militancia, hasta que los Constituyentes de 1857, teniendo en cuenta, entre otras cosas, que uno de los principales responsables de las perturbaciones del país, había sido el ejército pusieron fin a sus privilegios, estableciendo en el artículo 13 de la Constitución, que subsistía el fuero de guerra sólo para los delitos y faltas que tengan exacta conexión con la disciplina militar, dejando a las leyes secundarias el trabajo de fijar con claridad, los casos de esta excepción. De esta manera se consideraron que el fuero de guerra no constituía ya un privilegio; pero como no obstante, la actuación del ejército continuó siendo opresora de la libertad, puesto que su organización misma estaba basada en el reclutamiento forzoso, el sentimiento de hostilidad general contra esta institución no desapareció, y, al contrario, se exacerbó por la conducta observada por el mismo ejército, durante el gobierno del general Victoriano Huerta; lo que trajo por consecuencia que la revolución triunfante, procurara la absoluta desaparición del fuero militar, temiendo que cualesquiera que fueran las atenuaciones que se hicieran al sistema entonces establecido, resurgiera el antiguo militarismo. Existía por tanto, una impresión general desfavorable para las instituciones militares, en cuanto representan abuso de fuerza o situación privilegiada de alguna clase, por lo cual, los Constituyentes de 1917 no creyeron bastante la redacción del artículo 13 de

18 Semanario Judicial de la Federación, tesis aislada, Quinta Época, Pleno, México, t. XXXIX, p. 240. 
la Constitución de 1857, y lo reformaron en el sentido de que: "subsiste el fuero de guerra para los delitos y faltas contra la disciplina militar; pero los tribunales militares en ningún caso y por ningún motivo podrá extender su jurisdicción sobre personas que no pertenezcan al ejército. Cuando en un delito o falta del orden militar, estuviese complicado un paisano, conocerá del caso la autoridad civil que corresponda". La comparación entre los preceptos concordantes de las Constituciones de 1857 y 1917, ponen de relieve la marcada tendencia a restringir, hasta casi hacerlo desaparecer, el fuero de guerra, y si se le tolera en la actualidad, es porque se juzga necesario para mantener la disciplina en el ejército, opinión que no es unánime. De acuerdo con el texto de la Constitución vigente, para que el fuero de guerra subsista, se necesitan dos condiciones: que se haya cometido un delito militar, según características que la ley señala, y que el que lo haya cometido un miembro del ejército, pero puede suceder que en un delito militar estén complicados paisanos, y entonces se ofrecían al legislador Constituyente tres caminos para establecer la competencia: I, concederla a los tribunales militares; II, concederla a los tribunales civiles y, III, concederla a unos y otros, simultáneamente, para que los primeros juzgaran a los militares y los segundos a los paisanos; pero estudiando el artículo 13 constitucional, se deduce que no se optó por el primer camino, puesto que terminantemente se expresa que los tribunales militares en ningún caso podrán extender su jurisdicción sobre personas que no pertenezcan al ejército; ni tampoco por la tercera vía, porque estando en pugna con la doctrina universalmente reconocida, de que en ningún procedimiento judicial es conveniente que se divida la continencia de la causa, la circunstancia de que el artículo 13 no lo mande expresamente, bastaría por sí sola para hacer inaplicable tal práctica, puesto que las leyes que establecen excepciones generales, no son aplicables a caso alguno que no esté expresamente especificando en las mismas leyes; más aún, el simple análisis de las expresiones gramaticales del artículo que se comentan, lleva a esta deducción, pues dice: cuando en un delito o falta del orden militar estuviese complicado un paisano, conocerá del caso de la autoridad civil que corresponda. Ahora bien, la palabra complicado, sólo puede connotar, en la materia de que se trata, la idea de concurrencia de responsables diversos en la comisión de un delito; pluralidad de responsables que es precisamente la que determina ese tercer caso en que puede encontrarse un delito militar, y que viene indicar que el legislador sí lo tuvo en cuenta para establecer la competencia y que optó por el segundo de los caminos antes enunciados, estableciendo que debe ser la autoridad civil quien ha de conocer del proceso. Existe en el mismo artículo 13, otra palabra cuyo empleo viene en apoyo de las ideas expuestas y es la palabra caso; éste significa, en el lenguaje ordinario, suceso, acontecimiento, asunto que se propone a alguno para consultarle y oír su opinión, y el lengua- 
je forense, en la legislación española, se llama "caso de Corte", la causa civil o criminal que, por sus condiciones jurídicas, podía radicarse, desde luego, ante determinado tribunal, aun sacándola de su fuero o del domicilio de los litigantes. Dados estos antecedentes, tal palabra en el artículo 13 constitucional, no puede tener otra significación que la de acontecimiento originador del hecho delictuoso, del que debe conocer la autoridad civil, según ordena el citado precepto y no la de la responsabilidad del delincuente. La interpretación aceptada por la Corte, en alguna ejecutoria, sobre que los tribunales militares debían de conocer del proceso que se instruyera a los miembros del ejército y los civiles del que se abriera contra los paisanos, por razón del mismo delito militar, está en pugna con el principio de derecho, de la no división de la continencia de la causa, que tiende a evitar que, por razón de un mismo caso jurídico, se dicten dos fallos contradictorios. Cierto es que el Código Federal de Procedimientos Civiles no permite la acumulación de procesos, si se trata de diversos fueros, la que sólo puede llevarse a cabo cuando todo se encuentra en estado de instrucción; pero cuando el Constituyente, precisamente para no dar lugar a la división de la continencia, designó a las autoridades civiles para conocer de los procesos militares en que están inodados paisanos, no hay motivo alguno para que se sigan distintos procedimientos. De no aceptarse esta teoría, se imputarían al Constituyente las siguientes faltas: I, desconocimiento del lenguaje, por no haber usado con propiedad las palabras complicado y caso; II, faltas de previsión, por no establecer una regla para cuando los delitos del orden militar fueren cometidos conjuntamente por paisanos y militares; III, redundancia, al establecer, en la parte final de artículo 13, el mandato sobre que los tribunales militares no son competentes para juzgar a los paisanos y IV, repudiación de la teoría legal de la no división y IV, repudiación de la teoría legal de la no división de la continencia de la causa. En virtud debe concluirse: que ni los antecedentes históricos del artículo 13 constitucional, ni las condiciones sociales reinantes cuando fue expedido, ni las ideas expuestas por los legisladores al expedirlo, ni la significación gramatical de las palabras de su texto, pueden autorizar la interpretación de que cuando en un delito militar estuviese complicado un paisano, las autoridades del fuero de guerra juzgarán a los miembros del Ejército y las autoridades civiles al paisano; y por tanto, son las autoridades civiles quienes deben de conocer de un proceso militar en el que se encuentren inmiscuidos militares y paisanos; pero debe advertirse que el conocimiento corresponde a los Jueces Civiles, con el simple carácter de auxiliares de la Justicia Federal, porque tratándose de la aplicación de leyes militares, que tiene el carácter de leyes federales, a los Jueces de Distrito corresponde el conocimiento del pro- 
ceso, según lo dispone la fracción III del artículo 40 de la Ley Orgánica del Poder Judicial de la Federación. ${ }^{19}$

Esta discusión, generada en dos momentos de esta Suprema Corte y desde dos perspectivas diferentes, parecía haber sido zanjada cuando el Pleno de esta Suprema Corte de Justicia resolvió la competencia 118/37, suscitada entre el Juzgado Tercero Militar de la Plaza de México y el Segundo de lo Criminal de Puebla, a partir de la cual, se impuso la interpretación que resultaba conforme con el artículo 57 del Código de Justicia Militar, que en su fracción II reintroduce un criterio personal para otorgar competencia a los tribunales militares. Sin embargo, la discusión no se considera concluida ya que nunca se llevó a cabo una interpretación íntegra de la norma constitucional a fin de establecer cuál es el criterio (personal o material) que ella permite para la actualización de la competencia militar. Dicho asunto dio lugar a la tesis de rubro y texto siguientes:

\begin{abstract}
ARTÍCULO 13 CONSTITUCIONAL. SU INTERPRETACIÓN EN ORDEN A LA COMPETENCIA PARA CONOCER DE LOS DELITOS MILITARES, CUANDO CONCURRAN AGENTES CIVILES Y MILITARES EN LA COMISIÓN DE AQUELLOS. Diversas ejecutorias de la Suprema Corte sostuvieron, que el espíritu del último párrafo del referido artículo, es el de que un solo juez conozca del proceso que se instruye contra militares y civiles, a fin de evitar que se divida la continencia de la causa; y que, en tal caso, debe darse la preferencia para conocer del asunto a la autoridad civil correspondiente. Dichas ejecutorias fueron contrariadas a partir de la fecha en que se pronunció la resolución referente a la competencia con motivo del proceso instruido contra el general... Este, y sucesivos fallos, declararon: I. El artículo 13 constitucional prohíbe que un civil sea juzgado por tribunales militares en todo caso. II. Manda que las personas que pertenezcan al ejército sean enjuiciadas ante los tribunales del fuero de guerra. III en el caso de concurrencia de agentes civiles y militares en la comisión de un delito del orden militar, la autoridad civil correspondiente debe conocer del delito o caso de los civiles, y las autoridades del fuero de guerra de los que se imputan a los militares. Tal jurisprudencia, aunque fue contradicha en un caso posterior el de la competencia suscitada con motivo del proceso instruido en contra del sargento... se funda en razonamientos que deben ser aceptados para fijar definitivamente la interpretación del artículo 13 constitucional en orden a la competencia para conocer de los delitos militares. Aplicando las tesis sustentadas por la referida jurisprudencia, la controversia actual debe ser
\end{abstract}


resuelta en el sentido de que corresponde al fuero militar conocer del proceso instruido contra el comandante de la defensa rural de Santo Tomás Chiautla, debiendo remitirse al Juzgado del fuero común copia de lo conducente por lo que toca al acusado civil, a fin de que continúe los procedimientos. ${ }^{20}$

Del contenido de la tesis aislada antes citada se observa que lo que hizo en ese momento la Corte, fue ajustar el contenido de la norma secundaria al texto constitucional, pero no se llevó a cabo un análisis respecto a si el artículo 13 constitucional permitía adoptar el criterio personal recogido en el artículo 57 del Código de Justicia Militar.

Resulta evidente que el devenir histórico legislativo del artículo 13 constitucional indica que la competencia de los tribunales militares sólo se actualiza para conocer de los delitos y faltas con exacta conexión con la disciplina militar. En tanto que el devenir histórico jurisdiccional nos muestra una discrepancia, ya que no ha sido analizada la norma constitucional en su integralidad y ello ha impedido que se haga un contraste completo de la norma secundaria (Código de Justicia Militar) con la norma constitucional (artículo 13).

En este sentido, se considera que el planteamiento de la quejosa no ha sido contestado; esto es: hasta ahora la Corte no ha pronunciado una respuesta concluyente a la siguiente pregunta: ¿el artículo 13 constitucional prohíbe que los tribunales militares conozcan de asuntos que versan sobre delitos del orden común o federal y/o en los que está involucrado un civil como sujeto pasivo? Pues bien, se considera que la respuesta a la pregunta debe ser en sentido afirmativo. La siguiente interpretación permite llegar a tal conclusión.

\section{Interpretación constitucional}

La porción del artículo 13 constitucional cuyo alcance ha de ser interpretado establece: "Cuando en un delito o falta del orden militar estuviese complicado un paisano, conocerá del caso la autoridad civil que corresponda".

Todo el problema se circunscribe al hecho de que la expresión "estuviese complicado un paisano" ha sido entendida como si únicamente se refiriera al hecho en el cual el civil o paisano participa en la comisión del 
delito o falta del orden militar como sujeto activo del delito; sin embargo, se ha dejado de lado que también podría estar complicado o involucrado como sujeto pasivo o víctima del delito, posibilidad que sin duda cabe en el texto constitucional.

Como se ha establecido en párrafos anteriores, la Suprema Corte de Justicia de la Nación en tesis aisladas ha hecho algunas interpretaciones del artículo 13 constitucional que coinciden con la posición según la cual el fuero de guerra es sólo para delitos y faltas contra la disciplina militar y que carece de competencia para conocer de un delito o falta del orden militar si hay un paisano o civil complicado. Sin embargo, esta Corte también ha sostenido criterios en los que estos aspectos varían, pero omitiendo interpretar el contenido de lo establecido en la norma constitucional en cita.

Con motivo de esta falta de uniformidad, a lo largo de aproximadamente 40 años — pues dichas tesis se emitieron en la Quinta ${ }^{21}$ y Sexta Época ${ }^{22}$ se ha generado una práctica interpretativa que ha permitido que en todos los casos en que haya involucrado un militar como sujeto activo del delito y un paisano como sujeto pasivo o víctima del delito, el caso se tramite ante el fuero de guerra al menos en cuanto al proceso penal y emisión de sentencia.

Ante la falta de una interpretación uniforme del artículo 13 constitucional y para analizar lo expuesto en el presente caso, se debe iniciar por establecer de manera clara cuáles son los límites constitucionales para la actualización de la competencia del fuero militar.

Previamente es necesario dar contestación a algunas preguntas relevantes, mismas que permitirían dilucidar una posible respuesta al específico reclamo de constitucionalidad planteado por la quejosa.

Así, una vez analizados los antecedentes históricos del artículo 13 constitucional, en primer lugar es preciso analizar si el fuero militar es un fuero de excepción y, en su caso, por qué.

Como se ha hecho notar, los debates del constituyente de 1917 con respecto al artículo 13 constitucional giraron en torno a la específica pregunta de si los tribunales militares debían o no seguir existiendo. La duda

21 La Quinta Época de la Suprema Corte de Justicia de la Nación fue del 1o. de junio de 1917 al 30 de junio de 1957.

22 La Sexta Época de la Suprema Corte de Justicia de la Nación fue del 1o. de julio de 1957 al 15 de diciembre de 1968. 
que entonces se planteó el Constituyente no era gratuita; reconoció que tal fuero se destacaba por haber cometido abusos significativos en contra de la población civil. Pues bien, esta preocupación queda evidentemente plasmada en los debates. Por tanto, resultaría un contrasentido atribuir al Congreso constituyente la intención de ampliar, en vez de acotar, los supuestos para la actualización de la competencia militar. Resulta además claro que no es accidental la carga del lenguaje empleado por el Constituyente al señalar que: los tribunales militares en ningún caso y por ningún motivo podrán extender su jurisdicción sobre personas que no pertenezcan al Ejército.

El énfasis puesto en la prohibición de extender la jurisdicción militar a civiles y su colocación en el capítulo de garantías individuales claramente indica que, como afirma la quejosa, el artículo 13 constitucional estaba destinado a cumplir la función de proteger a los ciudadanos de cualquier posible abuso por parte del Ejército antes que proteger cualquier otro bien.

De esta forma, el Constituyente tuvo la expresa intención de fijar límites claros a la competencia del fuero militar, mismo cuyas facultades - consideró- debían acotarse con del fin de evitar determinados males cuyas consecuencias advirtió y consideró indeseables. Atendiendo a esa intención y al sentido literal del artículo 13 constitucional se siguen las siguientes conclusiones:

a) El fuero de guerra es sólo para delitos y faltas contra la disciplina militar.

b) El fuero de guerra sólo puede juzgar a militares.

c) El fuero de guerra carece de competencia para conocer de un delito o falta del orden militar si hay un paisano o civil complicado.

Ahora bien, cabe preguntar lo siguiente: ¿Tiene relevancia constitucional haber identificado que la regla que da competencia a los tribunales militares tiene un carácter excepcional?

Esta pregunta debe contestarse en sentido afirmativo. En efecto, la intención del Constituyente que ha sido identificada se traduce en un fin constitucionalmente ordenado. Esto no significa otra cosa que lo siguiente: la intención de acotar la esfera competencial de los tribunales militares fue plasmada en forma indubitable y en términos de una garantía constitucional. Esa intención de proteger a los civiles de posibles abusos tuvo un peso primordial. De hecho, la preservación de la disciplina 
militar se condicionó a que las garantías de los ciudadanos estuvieran protegidas.

Todo ello indica que las preguntas que se refieran al alcance de los límites del fuero militar, habrán de ser contestadas con miras al fin que anteriormente se ha identificado como propio del Constituyente de 1917. En esto radica la importancia de haber concluido que el fuero militar es un fuero cuya competencia se actualiza excepcionalmente.

Como se ha visto, existen razones autónomas derivadas del devenir histórico del artículo 13 constitucional que permiten considerar que la excepcionalidad del fuero militar es un principio orientador para correcta interpretación de sus alcances. Sin embargo, también resulta pertinente analizar si nuestro orden constitucional arroja razones adicionales que permitan considerar como un valor protegido el que los tribunales ordinarios conozcan de las controversias penales en general. Así, debe resolverse la siguiente cuestión:

¿Hay razones constitucionales que informan por qué es deseable que los tribunales ordinarios ejerzan jurisdicción sobre aquellas controversias penales que versan sobre conductas delictivas ajenas al orden militar o en las que interviene una civil en su carácter de ofendido o víctima? Lo anterior debe contestarse en sentido afirmativo.

La función jurisdiccional es ejercida por tribunales conformados por servidores públicos cuyo ingreso, permanencia y ascenso está condicionado a la observancia y satisfacción de ciertos principios. En efecto, la formación del juez (integrante tanto del Poder Judicial como de los órganos estatales) está orientada a servir ciertos fines constitucionales. De esta forma, el artículo 100 constitucional establece que la carrera judicial debe regirse por los principios de excelencia, objetividad, imparcialidad, profesionalismo e independencia. Asimismo, el artículo 116, fracción III de la Constitución Política de los Estados Unidos Mexicanos establece que la independencia de los magistrados y jueces (pertenecientes al Poder Judicial de los Estados) deberá estar garantizada, en el ejercicio de sus funciones, por las Constituciones y las leyes orgánicas de los estados. ${ }^{23}$

23 Refuerzan estos criterios las jurisprudencias de rubro: "Poderes judiciales de los estados. Marco jurídico de garantías establecido en el artículo 116, fracción III, de la Constitución federal" (P./J. 101/2000, Pleno, Semanario Judicial de la Federación y su Gaceta, t. XII, octubre de 2000, p. 32); "Magistrados de los poderes judiciales de los estados. en la interpretación de sus Constituciones, en la parte relativa a su designación, 
De acuerdo con el criterio establecido por la segunda de las jurisprudencias citadas al pie, ante diversas interpretaciones posibles de un precepto, debe optarse por aquella que permita que la labor jurisdiccional se desarrolle con libertad y sin injerencias externas, bajo el criterio de fortalecimiento del Poder Judicial, y de la realización plena de su autonomía e independencia, lo que exige la efectividad de las garantías jurisdiccionales.

Bajo esta línea debe recordarse que el diseño y estructura orgánica del Poder Judicial (tanto local como federal) no es gratuito, sino que responde a la preocupación de que distintos valores insertos en nuestra Constitución tengan plena efectividad. Entre ellos, la garantía de ser juzgados por tribunales ordenados en función de su autonomía frente a otros poderes. En procuración de esta garantía de carácter orgánico es que nuestra Constitución estableció que el fuero militar debía tener un carácter excepcional. Esto es, el Constituyente consideró valioso que las controversias penales fueran dirimidas por tribunales que reúnen determinadas características y que fueron diseñados en aras de generar un adecuado contrapeso entre poderes.

Tal intención fue expresada en el artículo 13 constitucional al disponer que: "Nadie puede ser juzgado por leyes privativas ni por tribunales especiales. Ninguna persona o corporación puede tener fuero, ni gozar más emolumentos que los que sean compensación de servicios públicos y estén fijados por la ley”. Esto es, tal disposición constitucional establece la obligación de que los tribunales que juzgan a ciudadanos iguales posean la misma estructura orgánica. Los tribunales militares carecen de ella.

Es oportuno aclarar que con esta interpretación no se sugiere que las cualidades de los tribunales militares son necesariamente incompatibles con aquellas que deben caracterizar a los tribunales ordinarios. Tal aseveración sería contraria a la decisión del Constituyente de 1917 de preservar el fuero militar en aras de proteger la disciplina militar.

Por ello, es necesario aclarar que con la interpretación aquí sugerida no se toma en cuenta si de facto los tribunales militares conducen sus

debe optarse por la que respete los principios consagrados en el artículo 116, fracción III, de la Constitución federal" (Semanario Judicial de la Federación y su Gaceta, P./J. 108/2000, Pleno, t. XII, octubre de 2000, p. 13); y "Poderes judiciales locales. La vulneración a su autonomía o a su independencia implica violación al principio de división de poderes" (Semanario Judicial de la Federación y su Gaceta, P./J. 79/2004, t. XX, septiembre de 2004, p. 1188). 
actuaciones de conformidad con tales principios. Un pronunciamiento de tal naturaleza resultaría ajeno a las facultades del Tribunal Pleno.

Así, sólo se está señalando que los tribunales formal y materialmente jurisdiccionales cuentan con una obligación (además exigible) de conducirse de conformidad con los principios de excelencia, objetividad, imparcialidad y profesionalismo; mismos que dan contenido y caracterizan el diseño orgánico de la jurisdicción ordinaria. Tales principios resultan garantías en favor de los gobernados. A mayor amplitud en su protección, más se favorece y respeta la intención del Constituyente de limitar los alcances del fuero militar a lo estrictamente necesario; a saber: la conservación de la disciplina militar.

Al respecto, se considera que la conservación de la disciplina militar no es una pretensión incompatible con la exigencia constitucional de que las controversias de índole penal (en las que estén involucrados civiles y militares) deban ser dirimidas por los tribunales que juzgan el resto de las causas ordinarias. Tribunales que están vinculados por el artículo 17 constitucional a conducirse de modo imparcial. Tribunales que deben rendir cuentas a los ciudadanos que juzgan mediante la debida motivación y argumentación de sus sentencias.

Si es cierto que la Constitución establece como jurisdicción preferente a la de los tribunales civiles, procede preguntar: ¿Hay alguna justificación constitucional para considerar que el grado en que tal garantía ha de protegerse debe variar en razón de la calidad de la persona que está involucrada en el proceso penal? Para dar contestación a lo anterior resulta necesario analizar quiénes son los sujetos involucrados en el proceso penal.

La reforma de 2000, mediante la cual se incluyó el apartado B del artículo 20 constitucional, obedeció al objetivo específico de proteger los derechos de la víctima u ofendido en el proceso penal. Las cláusulas previstas en esa disposición implican el deber de todos los órganos del estado de reconocer que la víctima u ofendido ha de tener un lugar relevante en la conducción del proceso penal; esto es, tiene la garantía de participar activamente en el proceso penal.

Por tanto, con motivo de la reforma del año 2000, la víctima y el ofendido fueron figuras cuyos derechos se elevaron a rango constitucional. La lectura del artículo 20, apartado B, de la Constitución Política de los Estados Unidos Mexicanos nos indica que el ofendido tiene reconocida, 
ante todo, la posibilidad de intervenir, alegar, demostrar y aportar elementos al proceso penal mediante el cual se juzga una causa en la que puede llegar a tener afectación.

Se considera que el reconocimiento de esos derechos obedece a una misma razón; a saber: la de buscar integrar de forma directa la voz de la víctima $u$ ofendida en aquellos procesos en los cuales el juez debe emitir un juicio acerca de la verdad de una imputación penal. Esto es, el propósito central de la reforma fue involucrar a la víctima u ofendido directamente en el proceso mediante el cual un juez imparcial debe resolver un conflicto entre dos partes: lugar en donde ya debía estar representada.

El órgano que ejerce la defensa en favor de la víctima u ofendido y del ofendido es el Ministerio Público, en su carácter de representante social. Sin embargo, hasta antes de la adición del apartado B del artículo 20 constitucional, la obligación del Ministerio Público de representar a la sociedad era un postulado que no tenía como reflejo la expresa consagración de derechos en favor de las personas a quienes tal órgano estaba llamado a tutelar. La necesidad de incluir esos derechos de participación e intervención en el proceso ( $\sin$ garantía de resultado alguno, por ejemplo, una sentencia condenatoria) fue lo que condujo al Constituyente Permanente a considerar que la víctima u ofendido debía ser considerada una parte más.

Se podría pensar que de considerar que la víctima o el ofendido son partes del proceso, la intensidad en la protección de los derechos del inculpado requeriría un equilibrio, como si los derechos de la víctima u ofendido fuesen derechos a exigir castigo. Esta concepción es errónea. Los derechos establecidos por el artículo 20, apartado B de la Constitución son sobre todo oponibles al Estado. Esto es, la víctima o el ofendido pueden exigir que el Ministerio Público les represente efectivamente y que, en su caso, el juez de la causa determine el deber de reparar a su favor el daño causado. Bajo esta interpretación, los valores insertos en nuestra Constitución se maximizan de forma integral; de manera tal que ninguno de ellos se entiende contrapuesto a otro.

Ambas clases de derechos se caracterizan por ser plenamente exigibles al Estado. Así, tanto el inculpado puede exigir al Estado que se respeten los postulados de un debido proceso, como la víctima u ofendido puede exigir que el Ministerio Público —en su calidad de órgano encargado de representar sus intereses-, conduzca sus actuaciones de conformidad con tal fin. 
Habiendo aclarado lo anterior, es claro que la interpretación constitucional planteada por la ofendida no sólo debe responderse analizando el contenido del artículo 13 constitucional sino también el del artículo 20, en su apartado B. De esta forma, este Tribunal Pleno llega a la conclusión de que la víctima y el ofendido son entes obligadamente involucrados en el proceso penal. Ahora bien, si el artículo 13 constitucional prohíbe la actualización de la competencia del fuero militar en el caso de que un civil esté involucrado, queda entonces claro que cuando la víctima u ofendido tienen el carácter de civiles, la competencia militar habrá de ser excluida.

En otras palabras, el artículo 20, apartado B, de la Constitución Política de los Estados Unidos Mexicanos obliga a considerar que la expresión "complicado un paisano" contenida en el artículo 13 constitucional debe leerse en el sentido de que la víctima u ofendido también es un sujeto involucrado o, si se quiere, complicado.

El significado de la frase "estuviese complicado un paisano" no puede depender tan sólo del significado lexicográfico del término "complicado", puesto que el uso lingüístico del mismo no responde al uso que la comunidad lingüística de México comúnmente da al mismo. Es evidente que se trata de más bien de una redefinición establecida en la ley para dar a la expresión el sentido de "involucramiento" más que de "complicación". En consecuencia, la fuerza comunicativa de la expresión ha de entenderse en el sentido de que el paisano puede estar involucrado en los hechos de que se trate, ya sea como sujeto activo o como sujeto pasivo del delito.

Por tanto, la víctima u ofendido no pueden considerarse como sujetos excluidos de la relación procesal que se actualiza en cualquier proceso penal. Si los tribunales están obligados a emitir juicios imparciales, es porque existen dos partes, cuyos intereses se encuentran en conflicto. Por ello, si el ofendido y la víctima pueden hacer valer derechos en el juicio y si su participación se encuentra garantizada, es claro que la Constitución también reconoce que la culminación de la sentencia respectiva tiene alcance sobre sus intereses.

Así, no se encuentra justificación alguna para suponer que el sujeto pasivo de un delito (cuyos derechos de participación ya han sido identificados) debe someterse a un fuero cuya justificación constitucional se condicionó a que ningún civil estuviere implicado o involucrado. 
En efecto, la intención de acotar el ámbito competencial de los tribunales militares obedeció a la consideración de que ningún civil debía ser sometido a la justicia castrense (artículo 13 constitucional). Si la Constitución, a partir de la inserción del artículo 20, apartado B, indica que la jurisdicción de los tribunales en los procesos penales también se extiende al ofendido y a la víctima, es entonces claro que resulta inconstitucional la norma legal que permite violar esa condición protegida.

Se estima que además es necesario realizar una distinción entre el concepto de someter a jurisdicción (actividad prohibida por el artículo 13 constitucional cuando un civil se halla involucrado) y el de juzgar. El primero es un concepto más amplio que el segundo. Bajo este entender, resulta evidente que la víctima u ofendido no es juzgada; sin embargo, ello no excluye que los efectos de la jurisdicción no le afectan. Ello es así porque el sujeto pasivo es parte de la litis que en esa jurisdicción se dirime.

Por otro lado, debe destacarse que la inconstitucionalidad de la competencia militar en casos en los que un ofendido o víctima civil está involucrada, no deviene del hecho de que el Código de Justicia Militar vigente impide participación a la víctima u ofendido en el mismo. Ello, al no regular debidamente los derechos establecidos en su favor en el artículo 20, apartado B de la Constitución Política de los Estados Unidos Mexicanos.

No pasa desapercibido el hecho de que el artículo 439 del Código de Justicia Militar ${ }^{24}$ establece que la víctima o el ofendido tienen el derecho a coadyuvar con el Ministerio Público y los demás a que se refiere el último párrafo del artículo 20 constitucional. Sin embargo, el párrafo respectivo se adicionó el 22 de julio de 1994. Ello indica que los términos en que está protegida la víctima u ofendido en el Código de Justicia Militar no corresponden a los de la reforma constitucional del año 2000 en la que se incorporaron los derechos de la víctima u ofendido. Por tanto, resultaría inadecuado afirmar que el sujeto pasivo del delito se encuentra

24 Artículo 439. En los procesos sólo serán considerados como partes, el Ministerio Público, el procesado y sus defensores.

(Adicionado, Diario Oficial de la Federación del 22 de julio de 1994). La víctima o el ofendido por algún delito tienen el derecho a coadyuvar con el Ministerio Público y los demás a que se refiere el último párrafo del artículo 20 constitucional. 
protegido en el Código de Justicia Militar con el mismo alcance que la Constitución ordena.

El vicio de inconstitucionalidad deviene del solo hecho de que el artículo 13 constitucional (por razones que el Constituyente creyó conveniente proteger) prohíbe que un tribunal militar conozca del caso en que un civil esté involucrado. Si toda parte está necesariamente involucrada en el todo y la víctima o el ofendido tienen reconocida intervención activa en el proceso, es entonces claro que están complicados en él. Si el artículo 13 constitucional prohíbe que un civil esté involucrado en procesos de índole militar, entonces también es claro que, ante el caso en que la víctima y el ofendido tienen el carácter de civiles, se actualiza la exclusión de la competencia militar.

Este es el contenido de la garantía constitucional contenida en el artículo 13 de la Constitución Política de los Estados Unidos Mexicanos, cuyo contenido no debe leerse aislado de los artículos 17 y 20, apartado $\mathrm{B}$ de la propia carta magna.

Se podría alegar que si el Código de Justicia Militar agregara derechos específicos para la víctima u ofendidos (derechos reconocidos en el artículo 20, apartado B) entonces habría una omisión subsanada y que ello sería motivo suficiente para señalar que, al estar garantizada la participación de la víctima u ofendido en ese fuero, no debería haber afectación alguna. Esto es erróneo, pues equivale a omitir notar que la garantía constitucional contenida en el artículo 13 constitucional ordena que la sola intervención de un civil basta para excluir el fuero militar. No se requieren razones adicionales para apreciar tal prohibición.

Así, debe aclararse que no se está señalando que los tribunales militares carecen de la obligación de conducirse con imparcialidad y con respeto al principio de legalidad. Por el contrario, estos deben conducirse de conformidad con los mismos; sin embargo, el Pleno no hubiera podido cuestionar las razones por las que el Constituyente determinó prohibir que los militares conocieran de asuntos penales en los que estuviera involucrado un civil. Ello es una garantía constitucional que debe protegerse con independencia de las razones que pudieran alegarse en el sentido de que es injustificado hacer distinciones entre los tribunales ordinarios y los militares. El Constituyente consideró que sí había una diferencia; tan es así que determinó que el fuero militar debía ser un tribunal de 
excepción constreñido exclusivamente a conocer de faltas propias de la disciplina militar.

Ahora bien, la conclusión anterior también se obtiene con la sola interpretación del artículo 13 constitucional. Ello en virtud de lo que sigue:

Ya se ha concluido que del artículo 13 constitucional se desprende, principalmente, un criterio material que delimita las condiciones en que el fuero militar tiene facultades para ejercer su jurisdicción; a saber: tratándose, exclusivamente de delitos o faltas que atentan contra la disciplina militar.

Al interpretar la expresión controvertida de esta forma, se recupera el criterio material, establecido en rango constitucional al menos desde 1857, y se deja a un lado un criterio personal. En esa medida, se estima que las interpretaciones que se dieron en la Quinta y principalmente en la Sexta Época son inconsistentes con el texto constitucional.

En primer lugar, porque, como se advierte en párrafos anteriores, desde los trabajos del Constituyente de 1917 existieron intenciones de limitar el fuero de guerra únicamente para los casos en que se estuviese en guerra o el ejército estuviera en campaña en alguna región del país. Fuera de esas situaciones de excepción, el Código Militar debía ser aplicado por tribunales civiles. ${ }^{25}$

Esto es, desde entonces resultaba claro que los civiles no debían ser sujetos a la jurisdicción militar y que ésta sólo era aplicable para militares, pero que además, el que no se sometiera a un civil a este fuero constituía una garantía. De esto puede desprenderse que la intención del Constituyente era que cualquier caso en el que hubiera un civil "complicado" fuera motivo suficiente para que conocieran las autoridades civiles, sin importar si el civil era sujeto activo o pasivo del delito.

De ahí surge la primera inconsistencia de las interpretaciones dadas anteriormente, pues considerar que un civil sólo puede verse involucrado cuando es sujeto activo del delito, es establecer un sistema mixto (material y personal), dejando de lado lo ordenado por la norma constitucional que establece como único el criterio material.

La Suprema Corte había establecido que la palabra "complicado" utilizada en el artículo 13 constitucional sólo puede connotar, en la materia

25 Cfr. Voto particular del general Francisco J. Múgica, Presidente de la Comisión del artículo 13, al dictamen del 5 de enero de 1917, Diario de Debates del Constituyente de 1917. 
de que se trata, la idea de concurrencia de responsables diversos en la comisión de un delito. ${ }^{26}$

Es importante tener en cuenta además, que la Suprema Corte ha concluido desde la misma Quinta Época que ni los antecedentes históricos del artículo 13 constitucional, ni las condiciones sociales reinantes cuando fue expedido, ni las ideas expuestas por los legisladores al expedirlo, ni la significación gramatical de las palabras de su texto, pueden autorizar la interpretación de que cuando en un delito militar estuviese complicado un paisano; las autoridades del fuero de guerra juzgarán a los miembros del Ejército y las autoridades civiles al paisano y, por tanto, son las autoridades civiles quienes deben de conocer de un proceso militar en el que se encuentren inmiscuidos militares y paisanos. ${ }^{27}$

Por lo demás, para lograr una clara interpretación que unifique lo hasta ahora dicho por esta Suprema Corte en la Quinta y Sexta Época y que han generado en la práctica inseguridad jurídica que ha sido motivo de inconformidades, incluso en el ámbito internacional, es importante aclarar lo siguiente: si el Constituyente de 1917 hubiese querido dar a la parte final del artículo 13 el sentido con el que ha sido interpretado en algunos criterios de la Suprema Corte de Justicia de la Nación, resultaba innecesaria la expresión previa que contiene el referido artículo, misma que dice: "los tribunales militares en ningún caso y por ningún motivo podrán extender su jurisdicción sobre personas que no pertenezcan al Ejército".

Esto es, sería repetitivo, ilógico e inútil que en el mismo párrafo del mismo artículo se dijera dos veces y de dos formas distintas algo que significa lo mismo:

a) Los tribunales militares en ningún caso y por ningún motivo podrán extender su jurisdicción sobre personas que no pertenezcan al Ejército, y

b) Cuando en un delito o falta del orden militar estuviese complicado un paisano, conocerá del caso la autoridad civil que corresponda.

Lo que aquí se distingue con el inciso acabado de identificar como a), debe interpretarse de la siguiente forma: sólo los militares pueden ser sujetos a este fuero, pero nunca podrá serlo un civil o de manera genérica una persona que no pertenezca al Ejército. Lo que significa que, aun cuando un civil cometiera un delito o falta a la disciplina militar, o

26 Semanario Judicial de la Federación, tesis aislada, Quinta Época, Primera Sala, t. LVIII, p. 1875.

27 Ibidem, Pleno, t. XL, p. 1393. 
incluso cualquier otra conducta o delito, no podría ser sometido al fuero de guerra bajo ninguna circunstancia. Esta es, además, una conclusión compatible con estándares internacionales.

En tanto que el inciso identificado como b) significa que cuando exista un delito o falta al orden militar en el que esté involucrado un paisano, independientemente si actúa de manera activa o pasiva, quien debe conocer de esa conducta necesariamente es la autoridad civil. Es decir, que ante un delito o falta al orden militar en el que esté involucrado un civil, por el simple hecho de que haya un civil, excluye a la jurisdicción militar y es la jurisdicción civil la que debe conocer. Esta parte del texto tenía como fin dar un paso más para excluir la competencia de los tribunales militares. Si este paso no diera, significaría lo mismo que el inciso a).

Si al aquí identificado como inciso b) se le entendiera en el sentido de que sólo comprende el supuesto en el que un civil es sujeto activo de un delito o falta al orden militar, ello significaría limitar el alcance y fin de la norma. Para cubrir ese supuesto, resultaba suficiente que el Constituyente normara lo que se ha identificado como inciso a).

Es decir, que con el contenido del mencionado inciso a) estaba cubierto el supuesto en el que un civil comete un delito o falta militar y no puede ser sometido a la jurisdicción militar al ser un "no militar" y en esa medida, esta última porción normativa de nada serviría; incluso sobraría del texto del artículo 13 constitucional.

Por tanto, resulta claro que el texto constitucional en esas dos partes normativas otorga dos garantías a los ciudadanos o cubre dos supuestos en los que se puede ver involucrado un civil o paisano cuando se comete un delito o falta al orden militar:

1. Como sujeto activo del delito o falta al orden militar, no puede ser sujeto a la jurisdicción de tribunales militares, y

2. Como sujeto pasivo del delito o falta a la disciplina militar, el caso debe ser conocido por la autoridad civil que corresponda.

Lo que es lo mismo, la Constitución establece dos excepciones claras a la competencia de los tribunales militares cuando se cometen delitos o faltas al orden militar:

1. Que una persona no militar (civil) en ningún caso puede ser sometido a la jurisdicción militar o fuero de guerra (sujeto activo), y 
2. Que si hay un civil complicado en un delito o falta, quien debe conocer es la autoridad civil (sea como sujeto activo y/o sujeto pasivo).

Si aun frente a todo lo antes expuesto - que recoge desde los fines que tenía el Constituyente hasta lo ilógico que sería tener dos porciones normativas con el mismo significado en un mismo artículo- se sigue dudando sobre si un tribunal militar tiene competencia para conocer del supuesto en el que un civil es sujeto pasivo del delito o falta al orden militar, entonces la cuestión debe ser resuelta teniendo en cuenta el principio pro persona en su vertiente de preferencia normativa. Esto significa que ante una pluralidad de posibles interpretaciones de dichas porciones normativas, o bien, una pluralidad de significados, contenidos y alcances de éstas, debe prevalecer la interpretación a la que anteriormente hemos arribado por ser la que mejor hace permanecer el derecho — garantía- y la que mejor tutela a la persona.

De esta manera, no se advierte que exista justificación constitucional alguna para suponer que hay una regla competencial diferenciada entre el caso en el que un civil interviene como sujeto activo y el caso en el que interviene en calidad de sujeto pasivo.

El artículo 17 constitucional establece como garantía constitucional el acceso a la justicia independiente e imparcial. Todas las personas protegidas por la Constitución Política de los Estados Unidos Mexicanos (sin distinciones) son titulares de la misma. Ahora bien, la independencia de los tribunales alude, en algún sentido, a la prohibición de injerencias de otros poderes en las determinaciones jurisdiccionales. Ahora bien, el Constituyente de 1917 tuvo la clara intención de que los civiles no fueran sometidos a una jurisdicción formalmente dependiente (como lo es el fuero militar); por ello, es claro que, de una lectura conjunta con el artículo 17 constitucional, y asumiendo que la víctima o el ofendido son titulares de la garantía del acceso a la justicia independiente, resulta entonces claro que no hay una razón justificada para distinguir entre el civil involucrado en calidad de sujeto activo y aquél involucrado en calidad de sujeto pasivo.

Ahora bien, una interpretación contraria a la anterior sólo tendría sentido de considerar que las conductas delictivas desplegadas por militares que ofenden bienes jurídicos de la sociedad civil deben ser juzgadas por un tribunal especial y distinto del que juzga cualquier otra controversia 
penal. No se encuentra previsión constitucional alguna que permitiera entender que ese es un fin cuya procuración debe garantizarse. La conservación de la disciplina militar no es un valor incompatible con la defensa de que la jurisdicción civil deba conocer de los casos en que la ofensa también es propiamente civil.

Finalmente, se debe señalar que la interpretación a la que se ha arribado es congruente con los estándares internacionales en materia de derechos humanos establecidos por diversos órganos internacionales de protección.

Esto es así porque el elemento esencial que se ha establecido respecto al fuero militar tanto en los instrumentos internacionales de derechos humanos como por los órganos de protección, es que los tribunales militares deben limitar su competencia a delitos y faltas de naturaleza estricta o exclusivamente militar cometidos por militares. Así se ha establecido, por citar sólo algunos ejemplos, que:

... los tribunales militares contribuyen a perpetuar la impunidad por su insuficiente independencia, resultante de la subordinación jerárquica a la que están sometidos todos o parte de sus miembros, su competencia deberá limitarse a las infracciones de carácter especificamente militar cometidas por militares, con exclusión de las violaciones de los derechos humanos, las cuales son competencia de los tribunales nacionales ordinarios... ${ }^{28}$

... la limitación de la jurisdicción de los tribunales militares exclusivamente a delitos especificamente militares, cometidos por personal militar. ${ }^{29}$

El Comité de Derechos Humanos de Naciones Unidas ha establecido, en algunos de sus informes y observaciones que recomiendan a los Estados partes, que las violaciones de los derechos humanos de los ciudadanos correspondan a la competencia de los tribunales civiles. ${ }^{30}$

28 Principio 31 del Conjunto de principios para la protección y la promoción de los derechos humanos mediante la lucha contra la impunidad, Documento de Naciones Unidas, E/CN.4/sub.2/1997/20/Rev.1, anexo.

29 Principios y directrices básicos sobre el derecho de las víctimas de violaciones de las normas internacionales de derechos humanos y del derecho internacional humanitario a interponer recursos y obtener reparaciones, Documento de Naciones Unidas, E/ CN.2/2000/62.

30 Comité de Derechos Humanos, Observaciones y recomendaciones a Colombia, 1992, Naciones Unidas, CCPR/C/79/Add.2, de 25 de septiembre de 1992, párrafos 5 y 6: "El Comité recomienda que el Estado parte... elimine el fenómeno de la impunidad... 
El Comité contra la Tortura de Naciones Unidas también se ha pronunciado a este respecto señalando que: “...no parece aceptable la escasa punibilidad del delito de tortura en el Código de justicia Militar, la extensión de la jurisdicción militar para conocer de delitos comunes a través de un alcance inadmisible del concepto de acto de servicio". ${ }^{31}$

Por su parte, el Comité de Derechos del Niño de Naciones Unidas manifestó en uno de sus primeros informes en que estudió el tema, que: "las violaciones de los derechos humanos y de los derechos de las niñas y los niños deberían ser examinados siempre por tribunales civiles de conformidad con el derecho civil, y no por tribunales militares". ${ }^{32}$

En el sistema europeo de derechos humanos también se ha establecido la importancia de que cuando se encuentra involucrado un civil y haya afectaciones a los derechos humanos, deban ser las autoridades civiles las que conozcan del caso, señalando que:

...el Tribunal confiere gran importancia al hecho de que un civil haya tenido que apelar ante una corte compuesta de miembros de las fuerzas armadas. Observa que el demandante pudo, legítimamente, experimentar temor en vista de que como uno de los jueces de la Corte era un juez militar, éste podía permitirse, indebidamente, ser influenciada por consideraciones ajenas a la naturaleza misma del caso... ${ }^{33}$

limite la competencia de los tribunales militares a las cuestiones internas de disciplina y asuntos análogos, de manera que las violaciones de los derechos humanos de los ciudadanos correspondan a la competencia de los tribunales civiles"; Comité de Derechos Humanos, Observaciones y recomendaciones a Venezuela, 1992, Naciones Unidas, CCPR/C/79/Add.13, de 28 de diciembre de 1992, párrafo 10. El Comité ha recomendado: "velar por que todos los miembros de las fuerzas armadas o de la policía que hayan cometido violaciones de los derechos garantizados en el Pacto [de Derechos Civiles y Políticos] sean juzgados y sancionados por tribunales civiles", y Comité de Derechos Humanos, Observaciones finales a Líbano, 1997, Naciones Unidas, CCPR/C/79/Add.76, de 5 de mayo de 1997, párrafo 34.

31 Comité contra la Tortura, Observaciones a Colombia, Naciones Unidas, A/51/44, de 9 de julio de 1996, punto 4. Se recomendó: "revisar la jurisdicción de los tribunales militares y traspasar a los tribunales ordinarios la competencia de los tribunales militares en todas las causas relativas a civiles y todos los casos de violación de los derechos humanos por miembros del ejército".

32 Comité de Derechos del Niño, Informe relativo a Colombia, Naciones Unidas, CRC/C/15/Add.30, de 15 de febrero de 1995, párrafo 17.

33 Corte Europea de Derechos Humanos, caso Ciraklar c. Turquia, sentencia de 28 de octubre de 1998; caso Greger c. Turquia, sentencia de 8 de julio de 1999. 
Por su parte, la Corte Interamericana de Derechos Humanos ha establecido, entre otras cosas, que: “...juzgar delitos comunes como si fueran militares por el solo hecho de haber sido ejecutados por militares, es violatorio de la garantía de un tribunal independiente e imparcial". ${ }^{34}$

Detallando más adelante que:

En un Estado democrático de derecho la jurisdicción penal militar ha de tener un alcance restrictivo y excepcional y estar encaminada a la protección de intereses jurídicos especiales vinculados con las funciones que la ley le asigna a las fuerzas militares. Así, debe estar excluido del ámbito de la jurisdicción militar el juzgamiento de civiles y sólo debe juzgar militares por la comisión de delitos o faltas que por su propia naturaleza atenten contra bienes jurídicos propios del orden militar... ${ }^{35}$

Cuando la justicia militar asume competencia sobre un asunto que debe conocer la justicia ordinaria, se ve afectado el derecho al juez natural y, a fortiori, el debido proceso, el cual, a su vez [se encuentra] íntimamente ligado al propio derecho de acceso a la justicia. ${ }^{36}$

Esos criterios establecidos por el tribunal interamericano, como se puede observar, se han venido reiterando y desarrollando a lo largo de al menos los últimos nueve años, en casos que incluyen a varios países de la región y en los cuales el hilo conductor es que en un Estado democrático la jurisdicción penal militar debe tener un alcance restrictivo $\mathrm{y}$ excepcional.

34 Corte IDH, Caso Genie Lacayo vs. Nicaragua. Fondo, reparaciones y costas. Sentencia de 29 de enero de 1997. Serie C, núm. 30, pfo. 53.

35 Corte IDH, Caso Durand y Ugarte vs. Perú. Fondo. Sentencia de 16 de agosto de 2000. Serie C, núm. 68, pfo. 117., Cfr Caso Palamara Iribarne. Sentencia de 22 de noviembre de 2005. Serie C, núm. 135, pfo. 124; Caso de la "Masacre de Mapiripán”, Fondo, reparaciones y costas. Sentencia de 15 de septiembre de 2005. Serie C, núm. 134, pfo. 202; y Caso 19 Comerciantes, Fondo, reparaciones y costas. Sentencia de 5 de julio de 2004. Serie C, núm. 109, pfo. 165.

36 Cfr. Caso Castillo Petruzzi y otros. Sentencia de 30 de mayo de 1999. Serie C, núm. 52, pfo. 128; Caso La Cantuta, Fondo, reparaciones y costas. Sentencia de 29 de noviembre de 2006. Serie C, núm. 162, pfo. 142, Caso Almonacid Arellano y otros, Excepciones preliminares, fondo, reparaciones y costas. Sentencia de 26 de septiembre de 2006. Serie C, núm. 154, pfo. 131 y Caso de la Masacre de la Rochela vs. Colombia. Fondo, reparaciones y costas. Sentencia de 11 de de mayo de 2007. Serie C, núm. 163, pfos. 200 y 204. 
Dentro del mismo sistema interamericano de derechos humanos, la Comisión Interamericana ha recomendado a los Estados partes al Pacto de San José que:

... adopten de conformidad con el artículo 2o. de la Convención [Americana], las medidas de derecho interno que sean necesarias para limitar la competencia y jurisdicción de los tribunales militares solamente a aquellos delitos que tengan exclusivo carácter militar, y en ningún caso se permita el juzgamiento de actos violatorios de los derechos humanos en cortes militares. ${ }^{37}$

Esta Comisión, incluso de manera concreta en un caso de México estableció que: “... la privación de libertad y la violación de las hermanas González Pérez no pueden de manera alguna considerarse hechos que afecten bienes jurídicos vinculados al orden militar". ${ }^{38}$

Para establecer de manera clara que cuando se trata de violaciones a los derechos humanos cometidas en contra de civiles, no hay razón alguna para que el fuero de guerra sea competente, la Comisión de manera categórica en la misma línea de argumentación anterior y para distinguir que sí es y que no es, un bien militar que debe ser protegido por su jurisdicción, señaló que:

... la masacre de civiles indefensos no puede ser considerada como parte de las funciones legítimas de los agentes de las fuerzas de seguridad. Consecuentemente, el hecho de que se haya otorgado competencia a la justicia castrense para juzgar a los presuntos autores intelectuales de las graves violaciones cometidas constituye una violación a... la Convención Americana. ${ }^{39}$

Este órgano interamericano en marzo de 2009, al celebrar su 134o. periodo ordinario de sesiones analizó la situación de la justicia militar, insistió en su preocupación de que en algunos países de la región se con-

37 Comisión Interamericana de Derechos Humanos, Informe anual 1992-1993, OEA/ Ser.L/V/II.83, doc. 14, cap. V, 12 de marzo de 1993, pfo. 6.

38 Comisión Interamericana de Derechos Humanos, Informe anual 2000, OEA/Ser./ L/V/II.111, doc. 20, Rev., 16 de abril 2001, Informe núm. 53/01, Ana, Beatriz y Cecilia González Pérez, caso 11.565 (México), pfo. 85.

39 Comisión Interamericana de Derechos Humanos, Informe anual 1999, OEA/Ser./ L/V/II.106, doc.3, 13 de abril 2000, Informe núm. 35/00, Los Uvos, caso 11.020 (Colombia), pfo. 61. En el mismo sentido el caso núm. 36/00, Caloto, caso 11.101 (Colombia), pfo. 56 . 
tinúa empleando la justicia militar para investigar y juzgar delitos comunes perpetrados por miembros de las fuerzas armadas o de la policía. Asimismo, reitero que la jurisdicción militar sólo debe ser utilizada para delitos de función, esto es, conductas de militares en servicio activo que atenten contra bienes jurídicos castrenses. ${ }^{40}$

Es de destacar que muchos de los estándares internacionales antes citados también son coincidentes con lo que, en calidad de Amicus Curiae en el caso, presentaron y ofrecieron la Clínica de Derechos Humanos de la Facultad de Derecho de la Universidad de Harvard, la Comisión Internacional de Juristas y la Oficina del Alto Comisionado para los Derechos Humanos de Naciones Unidas.

Criterios y decisiones en el mismo sentido se han establecido por otros órganos internacionales de protección de los derechos humanos. No obstante, es claro que los anteriores son ya suficientes para demostrar que la interpretación sugerida es compatible con las obligaciones internacionales del Estado mexicano, entre ellas, la consistente en que el fuero militar debe tener bien definida su competencia y no ocuparse de asuntos en los que se ven implicados civiles.

En este sentido, se puede señalar que para que el fuero militar sea compatible con los estándares internacionales, debe cumplir al menos con los siguientes elementos:

a) Estar destinado a juzgar sólo a militares por delitos militares.

b) Tener sólo competencia para conocer de delitos o faltas militares, esto es, aquellos que por su propia naturaleza atenten contra bienes jurídicos propios del orden militar.

c) No tener jurisdicción sobre civiles bajo ninguna circunstancia.

d) No tener competencia para conocer de asuntos en los que la víctima $\mathrm{u}$ ofendido sea un civil aunque el delito sea cometido por un militar, $\mathrm{y}$

e) No tener competencia para juzgar violaciones a los derechos humanos.

Similar conclusión emitió el Grupo de Trabajo sobre detención arbitraria de Naciones Unidas en $1999,{ }^{41}$ al proponer lo siguiente:

\footnotetext{
40 Cfr. Comisión Interamericana de Derechos Humanos, Comunicado de Prensa 13/09.

41 Comisión de Derechos Humanos, Grupo de trabajo sobre detención arbitraria, E/ CN.4/1999/63, pfo. 79.
} 
El Grupo estima que de subsistir alguna forma de justicia militar, debería en todo caso respetar cuatro límites:

a) debería declararse incompetente para juzgar a civiles;

b) debería declararse incompetente para juzgar a militares, si entre las víctimas hay civiles;

c) debería declararse incompetente para juzgar a civiles y a militares en los casos de rebelión, sedición o cualquier delito que ponga o pueda poner en peligro un régimen democrático;

d) no estaría en ningún caso autorizado a imponer la pena de muerte.

De esta manera, conociendo el origen y fines que el Constituyente le confirió al artículo 13 constitucional, la coherencia y lógica que debe tener dicha norma, la existencia de nuevos contenidos en el texto constitucional, así como las obligaciones internacionales que ha adquirido México, es de concluirse que la interpretación aquí sugerida del artículo 13 constitucional es congruente con el texto constitucional y con los estándares internacionales en materia de derechos humanos. Ello, en la medida en que se concluye que: cuando se trata de delitos contra la disciplina militar, en donde se involucre a un civil, sea como sujeto activo o pasivo, necesariamente debe ser la autoridad civil la competente para conocer del asunto, más aún, y sin excepción alguna, si dicho delito conlleva la violación de derechos humanos.

Como se ha expuesto, todos los órganos de protección internacional de los derechos humanos han establecido que los tribunales militares no deben juzgar a civiles y que las violaciones de derechos humanos cometidas por militares deben quedar bajo la jurisdicción de tribunales civiles. Estos principios, derivan esencialmente del contenido de la gran mayoría de los tratados sobre derechos humanos existentes tanto en el sistema universal como en los sistemas regionales de protección.

Así por ejemplo, los tratados base de jurisdicciones internacionales como el Pacto Internacional de Derechos Civiles y Políticos y la Convención Americana sobre Derechos Humanos, al ser interpretados por los órganos competentes para ello, han establecido como elementos básicos al hablar del debido proceso y la protección judicial, los dos principios que antes se señalan. De igual manera, otros tratados como el de Desaparición Forzada de Personas expresamente excluyen a la jurisdicción militar para juzgar a quienes cometan ese delito. 
Al respecto, es importante señalar que México hizo una reserva en la Convención Interamericana sobre Desaparición Forzada de Personas, que en su artículo IX ${ }^{42}$ establece la obligación para los Estados de juzgar a quienes cometan el delito de desaparición forzada ante jurisdicciones ordinarias y exceptuar especialmente a la jurisdicción militar de ello, además de evitar que se considere la comisión de esos hechos ilícitos como parte del ejercicio de las funciones militares. ${ }^{43}$

El contenido de dicha reserva no afecta los alcances de la interpretación que se ha hecho del artículo 13 constitucional en relación con el caso concreto sobre el que este voto versa. En efecto, la reserva a la que se ha hecho mención fue formulada por el Estado mexicano respecto de la Convención Interamericana sobre Desaparición Forzada de Personas, que como su nombre lo indica se dirige concretamente a ese delito, mismo que no es materia del proceso penal seguido ante el Juez Militar con motivo de los hechos que constituyen el antecedente del presente juicio de garantías. ${ }^{44}$

\section{Artículo IX}

Los presuntos responsables de los hechos constitutivos del delito de desaparición forzada de personas sólo podrán ser juzgados por las jurisdicciones de derecho común competentes en cada Estado, con exclusión de toda jurisdicción especial, en particular la militar.

Los hechos constitutivos de la desaparición forzada no podrán considerarse como cometidos en el ejercicio de las funciones militares.

No se admitirán privilegios, inmunidades, ni dispensas especiales en tales procesos, sin perjuicio de las disposiciones que figuran en la Convención de Viena sobre Relaciones Diplomáticas.

43 La reserva fue hecha al momento del depósito del instrumento de ratificación (9 de abril de 2002) y su contenido es el siguiente: "El Gobierno de los Estados Unidos Mexicanos al ratificar la Convención Interamericana sobre Desaparición Forzada de Personas, adoptada en la Ciudad de Belem, Brasil el 9 de junio de 1994, formula reserva expresa al Artículo IX, toda vez que la Constitución Política reconoce el fuero de guerra, cuando el militar haya cometido algún ilícito encontrándose en servicio. El fuero de guerra no constituye jurisdicción especial en el sentido de la Convención, toda vez que conforme al artículo 14 de la Constitución mexicana nadie podrá ser privado de la vida, de la libertad o de sus propiedades, posesiones o derechos, sino mediante juicio seguido ante los tribunales previamente establecidos, en el que se cumplan las formalidades esenciales del procedimiento y conforme a las leyes expedidas con anterioridad al hecho".

44 Actualmente, la reserva antes citada es la única que guarda relación en el presente asunto y una de las pocas que subsisten en tratados de derechos humanos ratificados por México, ya que el Estado mexicano eliminó y retiró varias en el año 2006. 


\section{Análisis del artículo 57, fracción II, apartado a) del Código} de Justicia Militar

Una vez analizado el contenido y alcances del artículo 13 constitucional, en cuanto a la competencia de los tribunales militares, corresponde ahora analizar si lo dispuesto en el artículo 57, fracción II, apartado a), del Código de Justicia Militar ${ }^{45}$ se ajusta o es compatible con, lo que se estima, son los alcances y exigencias de la garantía individual contenida en el referido precepto.

Toda norma jurídica tiene los siguientes elementos en su núcleo normativo: a) el carácter (o modalidad deóntica), que puede ser obligatorio (cuando indican que algo debe hacerse); prohibido (cuando indican que algo no debe hacerse); permitido (cuando indican que algo puede hacerse) y facultativo (cuando indican que algo puede hacerse de manera exclusiva por un sujeto determinado); b) el contenido de la norma es aquella acción u omisión que la norma indica que está prohibida, que es obligatoria o que está permitida; y c) las condiciones de aplicación: el conjunto de circunstancias que han de darse para que la norma deba ser cumplida. ${ }^{46}$

Siguiendo la anterior caracterización, podemos decir que el precepto que ahora nos ocupa tiene un carácter facultativo, pues, el sujeto normativo de la norma serán necesariamente los tribunales militares, esto es, aquellos que están facultados para conocer y resolver sobre los delitos contra la disciplina militar. El contenido de la norma es, precisamente, las acciones consistentes en delitos que hayan sido cometidos por militares. Finalmente, las condiciones de aplicación de la norma son: 1) que se

45 “Artículo 57. Son delitos contra la disciplina militar...

II. Los del orden común o federal, cuando en su comisión haya concurrido cualquiera de las circunstancias que en seguida se expresan:

a) Que fueren cometidos por militares en los momentos de estar en servicio o con motivo de actos del mismo...".

46 Los elementos que quedan fuera del núcleo normativo son: d) la autoridad: la persona u órgano de la que emana la norma; e) sujeto normativo: es el destinatario de la norma; f) ocasión: localización especio-temporal en el que es aplicable la norma; g) promulgación: la formulación de la norma en un lenguaje (oral o escrito); y h) sanción: la consecuencia que se sigue del incumplimiento o del cumplimiento. Esta caracterización se debe al finlandés George Henrik von Wright. Véase, de este autor, Norma y acción, traducción de P. García Ferrero, Madrid, 1979. 
cometan delitos del fuero común o federal, 2) que los hubieren cometido militares y 3) que esa comisión se hubiere originado cuando los militares estuvieren en servicio o con motivo de actos del mismo.

Es importante aclarar que esta norma no puede ser considerada de carácter obligatorio o de carácter prohibitivo (caso éste de los tipos penales), pues no establece un mandato dirigido a una persona para que haga o deje de hacer alguna conducta específica. Para que así fuera, la norma tendría que especificar qué conducta concreta (por ejemplo el tipo penal) está indicada como deber jurídico o está específicamente prohibida, en ambos casos por estar condicionada por una sanción.

Por otro lado, el precepto impugnado se encuentra localizado en el capítulo I denominado "Disposiciones preliminares" del título quinto identificado como "De la competencia" del Libro Primero titulado "De la organización y competencia" del Código de Justicia Militar; lo anterior indica que la organización topográfica del propio código confirma que se trata de una norma facultativa, en cuanto a su contenido se refiere a la competencia de que se dota a los tribunales militares al definir los delitos contra la disciplina militar, y en cuanto a su ejercicio es de naturaleza imperativa, esto es, no es discrecional para los tribunales el conocer o no de ese tipo de conductas.

Estamos, pues, ante una norma que confiere poderes públicos, cuyas condiciones de aplicación son hipotéticas, ya que señalan que para que ciertos delitos del fuero común o federal sean conocidos por los tribunales militares, es menester que los hubiere cometido algún militar en servicio o con motivo de éste.

Ahora bien, al tratarse el artículo impugnado de una norma que dota de competencia a los tribunales militares cuya existencia se encuentra reconocida y regulada en el artículo 13 constitucional, es evidente que la ley secundaria debe ajustarse a las exigencias y límites de la garantía constitucional.

Esto es así ya que el constituyente, tal y como se ha expuesto en el apartado precedente, al reconocer en Constitución la permanencia del fuero de guerra, estableció reglas concretas para su existencia y aplicación, concretamente, un criterio de índole material consistente en que dicho tipo de tribunales sólo pueden existir para conocer de delitos contra la disciplina militar. Aquí es importante señalar que el concepto de disciplina militar, como criterio material de competencia, se identifica con conductas específicas realizadas por miembros del ejército con las 
cuales se atenta o trasgreden principios inherentes a la actividad de los miembros de las fuerzas armadas; esto es, conductas que llegan a constituir delitos o faltas que solamente tienen sentido dentro de la dinámica de las fuerzas armadas.

Así, por ejemplo, en el Código de Justicia Militar se prevén, entre otros, como delitos: a) contra la seguridad exterior de la nación, tales como traición a la patria, espionaje, violación de neutralidad o inmunidad diplomática; ${ }^{47}$ b) delitos contra la seguridad interior de la nación, como la rebelión y la sedición;48 c) delitos contra la existencia y seguridad del ejército como lo son la falsificación, fraude, malversación y retención de haberes, extravío, enajenación, robo y destrucción de lo perteneciente al ejército, deserción e insumisión, inutilización voluntaria para el servicio, insultos, amenazas o violencias contra centinelas, guardias, tropa formada, salvaguardias, bandera y ejército, ultrajes y violencias contra la policía y falsa alarma; ${ }^{49} \mathrm{~d}$ ) delitos contra la jerarquía y la autoridad, entre los que se tipifican el de insubordinación, abuso de autoridad, desobediencia y asonada.

Sin embargo, en la porción normativa ahora impugnada, esto es, el apartado a) de la fracción II del artículo 57 del Código de Justicia Militar, se establece que son delitos contra la disciplina militar, y por ende, los tribunales militares tienen competencia para conocer de ellos, los previstos en los Códigos Penales del orden común o federal siempre que hayan sido cometidos por militares en el momento de estar en servicio o con motivo de actos del mismo.

De la simple lectura de la norma que fue impugnada, es evidente que adopta un criterio meramente personal para determinar la existencia de delitos contra la disciplina y militar, y por tanto, para dotar de competencia a los tribunales militares. Esto es, sólo se atiende a la calidad del sujeto activo, es decir, que se trate de un miembro del ejército en el momento de estar en servicio o con motivo de éste. Con ello se faculta a los tribunales militares para conocer de delitos tipificados en las legislaciones

47 Estos delitos se encuentra previstos en el título sexto del libro segundo del Código de Justicia Militar, concretamente en los artículos 203 a 217.

48 Estos delitos se encuentra previstos en el título séptimo del libro segundo del Código de Justicia Militar, concretamente en los artículos 218 a 227.

49 Estos delitos se encuentra previstos en el título octavo del libro segundo del Código de Justicia Militar, concretamente en los artículos 228 a 282. 
locales o federal ordinarias, esto es, no castrenses, siendo que en dichos ordenamientos - atendiendo a su naturaleza-, se prevén conductas que no tienen relación alguna con la disciplina militar (como podrían ser los delitos de homicidio, lesiones, violación, abuso sexual, privación ilegal de la libertad, contra la salud, etcétera).

Es precisamente en atención al carácter ordinario de ese tipo de delitos que en los mismos pueden estar relacionados, ya sea como sujetos activos o pasivos (víctima u ofendido), personas que tengan la calidad de civiles, mismos que en atención a la competencia atribuida por el precepto impugnado a los tribunales militares quedan indefectiblemente sometidos a la jurisdicción del fuero de guerra a pesar de que el delito, en sí mismo, no corresponde materialmente a los que se han identificado como que atentan contra la disciplina militar.

Esta distinción de los tipos de delitos en cuanto a su fuente normativa — si la conducta que en términos del artículo impugnado constituye un delito contra la disciplina militar, se encuentra en el Código de Justicia Militar o en un código penal del orden común o federal- no es una cuestión meramente formal. Ello tiene implicaciones sumamente trascendentes en los derechos que se reconocen a las partes que se encuentran relacionadas o vinculadas con la conducta delictiva, principalmente si se trata de la persona de la víctima o del ofendido.

Así, en un delito claramente relacionado con la disciplina militar, como lo sería el de deserción, no tendría cabida la existencia de la víctima u ofendido distinta del propio ejército; sin embargo, tratándose de un delito de homicidio o violación, es obvio que el daño o lesión al bien jurídico es resentido por personas físicas distintas a la institución castrense. Así, la víctima u ofendido está en posibilidad, conforme a lo dispuesto en el artículo 20, apartado B, de la Constitución Federal, de hacer valer diversos derechos que le son reconocidos, lo cual sólo puede ocurrir en la dinámica de un proceso en el que se le reconoce tal calidad. Ello no puede ocurrir de manera plena ante la justicia militar en donde no se le reconoce siquiera su existencia. En este sentido, tampoco puede afirmarse que sus intereses son representados por el Ministerio Público Militar, pues éste tiene el propósito de defender a la institución castrense en sí misma.

El efectivo ejercicio de los derechos que la Constitución reconoce a la víctima o al ofendido solamente se logra en la medida en que se reconoce que los delitos previstos en los códigos penales del orden común 
o federal no regulan conductas que atentan contra la disciplina militar (en las que el sujeto pasivo se puede identificar con la propia institución castrense), sino que las mismas atentan o lesionan bienes jurídicos de personas civiles.

En este contexto, se considera que el artículo 57, fracción II, apartado a), del Código de Justicia Militar es contrario a la garantía contenida en el artículo 13 constitucional, que establece la prohibición para que los civiles o paisanos se encuentren sometidos a la jurisdicción del fuero de guerra.

En consecuencia, en caso de que la mayoría hubiera determinado que la ofendida sí tenía legitimación para acudir al amparo, entrando así al fondo de la cuestión, se estima que su resolución hubiera debido ajustarse a las consideraciones aquí expuestas. De este modo, se considera que la mayoría debía haber amparado a la quejosa para el efecto de que fuera un juez federal ordinario quien conociera de la causa penal respectiva. 